\title{
PENGEMBANGAN BAHAN AJAR DENGAN MENGGUNAKAN PENDEKATAN SAINTIFIK UNTUK MENINGKATKAN KREATIFITAS SISWA DI KELAS X SEKOLAH MENENGAH ATAS
}

\author{
Fitri Agustina $^{1)}$ dan Jalilah Azizah ${ }^{1)}$ \\ ${ }^{1)}$ Fakultas Ilmu Keguruan dan Pendidikan Universitas Muhammadiyah Tapanuli Selatan \\ Fitri.agustina@um-tapsel.ac.id
}

\begin{abstract}
Abstrak
This study aims to produce a teaching material based on the scientific approach that is valid, practical, and effective and can increase creativity in biology learning in high school class X. The method used in this development is the 4-D Model (Four D Model) development model, which consists of four stages are: define, design, develop, and spread (disseminate). Development research is a research method for developing products and improving products. The defining stage is carried out by the determination of learning conditions by analyzing competency standards and boundaries of the subject matter that will be taught by the teacher based on the 2013 curriculum content standards. The planning stage for the preparation of instruments needed in this study and the design of prototype teaching materials. Development stage 1) expert appraisal followed by revision, and 2) development trials limited to students (developmental testing). Stage of dissemination (disseminate) by publishing teaching material that has been developed in the form of a journal. The ability of students has increased, this can be seen from the percentage of classical completeness of students in the first trial of $36 \%$, and the percentage of classical completeness of students in the second trial was $83 \%$. In other words an increase in the biological representation of students in the ecosystem material from the first trial to the second trial increased.
\end{abstract}

Keywords: Development, Teaching Materials, Creativity

\begin{abstract}
Penelitian ini bertujuan menghasilkan bahan ajar berbasis pedekatan saintifik yang valid, praktis, dan efektif serta mampu meningkatkan kreatifitas pada pembelajaran biologi SMA kelas X. Metode yang digunakan dalam pengembangan ini adalah model pengembangan 4-D Model (Four D Model), yang terdiri dari empat tahapan yaitu: pendefenisian (define), perancangan (design), pengembangan (develop), dan penyebaran (dessiminate). Penelitian pengembangan adalah metode penelitian untuk mengembangkan produk dan penyempurnaan produk. Tahap pendefenisian ini dilakukan penetapan syarat-syarat pembelajaran dengan menganalisis standar kompetensi dan batasan materi pelajaran yang akan diajarkan oleh guru berdasarkan standar isi kurikulum 2013. Tahap perencanaan penyusunan instrumen yang diperlukan dalam penelitian ini dan perancangan prototype bahan ajar. Tahap pengembangan 1) penilaian ahli (expert appraisal) yang diikuti dengan revisi, dan 2) uji coba pengembangan terbatas pada siswa (developmental testing). Tahap penyebaran (dessiminate ) dengan mempublikasikan bahan ajar yang telah dikembangkan dalam bentuk jurnal. Kemampuan siswa mengalami peningkatan, hal ini terlihat dari persentase ketuntasan klasikal siswa pada ujicoba I sebesar 36\%, dan persentase ketuntasan klasikal siswa pada ujicoba II sebesar 83\%. Dengan kata lain peningkatan representasi biologi siswa pada materi ekosistem dari ujicoba I ke ujicoba II mengalami peningkatan.
\end{abstract}

Kata Kunci: Pengembangan,Bahan Ajar, Kreatifitas

PeTeKa (Jurnal Penelitian Tindakan Kelas dan Pengembangan Pembelajaran) | 14 
Fitri Agustina dan Jalilah Azizah. Pengembangan Bahan Ajar dengan Menggunakan...

\section{PENDAHULUAN}

Kurikulum 2013 dalam proses pembelajaran menekankan tiga kompetensi yaitu kognitif, afektif dan psikomotorik. Agar siswa dapat mengembangkan kemampuan berfikir dengan baik maka kreatifitas harus ditingkatkan. Menurut Lufri (2007) Proses kreatifitas bentuk pemikiran individu berusaha menemukan hubungan-hubungan baru, mendapatkan jawaban, metode atau cara baru menghadapi masalah. Kreatifitas siswa yang diharapkan, memiliki rasa ingin tahu luas dalam pembelajaran, mengajukan pertanyaan baik dan kreatif, serta memberikan gagasan atau usul terhadap suatu masalah, kreatif menyatakan pendapat dan memiliki daya imajinasi.

Pendekatan saintifik diharapkan mampu menugaskan siswa untuk lebih aktif dalam proses pembelajaran di kelas dalam rangka mengkonstruksi pengetahuan dan keterampilannya, juga dapat mendorong siswa untuk melakukan penyelidikan guna menemukan faktafakta dari suatu fenomena atau kejadian. Artinya, dalam proses pembelajaran, peserta didik dibelajarkan dan dibiasakan untuk menemukan kebenaran ilmiah, bukan diajak untuk beropini dalam melihat suatu fenomena. Mereka dilatih untuk berfikir logis, runtut dan sistematis, dengan menggunakan kapasitas berfikir tingkat tinggi (High Order Thingking/HOT).

Bahan ajar penting digunakan dalam pembelajaran, karena bahan ajar berfungsi sebagai alat bantu dalam kegiatan pembelajaran. Darmawangsa (2017) mengatakan bahwa pada dasarnya proses pembelajaran dalam modul berhubungan dengan teks, terutama pada teks harus didukung dengan pendekatan.Bahan ajar berupa modul yang dirancang untuk dapat dipelajari secara mandiri oleh peserta didik. Bahan ajar berupa modul disebut juga media untuk belajar mandiri karena di dalamnya telah dilengkapi petunjuk untuk belajar sendiri. Artinya, pembaca dapat melakukan kegiatan belajar tanpa kehadiran pengajar secara langsung. Bahasa, pola, dan sifat kelengkapan lainnya yang terdapat dalam modul ini diatur sehingga ia seolah-olah merupakan "bahasa pengajar" atau bahasa guru yang sedang memberikan pengajaran kepada peserta didiknya.

SMA Negeri 5 di Kota Padangsidimpuan yang digunakan sebagai observasi awal. SMA Negeri 5 Padangsidimpuan kelas $\mathrm{X}$ terdiri dari 8 ruangan kelas. Pembelajaran biologi di kelas X ditemukan masih bermasalah dalam hasil belajar. Pemahaman siswa masih rendah, karena guru masih menggunakan buku sebagai media utama pembelajaran. Siswa hanya memahami biologi sebahagian dalam ranah kognitif, sedangkan lemah di keterampilan dan afektif. Oleh karena itu diadakan penelitian yang berjudul: "Pengembangan Bahan Ajar dengan menggunakan Pendekatan Saintifik untuk meningkatkan kreatifitas siswa di Kelas X Sekolah Menengah Atas”.

Direktorat Pembinaan Sekolah Menengah Atas (2008), bahan ajar adalah segala bentuk bahan yang digunakan untuk membantu guru dalam melaksanakan kegiatan belajar mengajar. Bahan yang dimaksud bisa berupa bahan tertulis maupun bahan tidak tertulis. Berdasarkan definisi-definisi tersebut, dapat disimpulkan bahwa bahan ajar merupakan komponen pembelajaran yang digunakan oleh guru sebagai bahan belajar bagi siswa dan membantu guru dalam melaksanakan kegiatan belajar mengajar di kelas.

Pengembangan suatu bahan ajar harus didasarkan pada analisis kebutuhan siswa. Terdapat sejumlah alasan mengapa perlu dilakukan pengembangan bahan ajar, antara lain: 1) Ketersediaan bahan sesuai tuntutan kurikulum, artinya bahan 
belajar yang dikembangkan harus sesuai dengan kurikulum, 2) Karakteristik sasaran, artinya bahan ajar yang dikembangkan dapat disesuaikan dengan karakteristik siswa sebagai sasaran, karakteristik tersebut meliputi lingkungan sosial, budaya, geografis maupun tahapan perkembangan siswa, 3) Pengembangan bahan ajar harus dapat menjawab atau memecahkan masalah atau kesulitan dalam belajar.

Dengan demikian, pengembangan bahan ajar di sekolah perlu memperhatikan karakteristik siswa dan kebutuhan siswa sesuai kurikulum, yaitu menuntut adanya partisipasi dan aktivasi siswa lebih banyak dalam pembelajaran. Pengembangan lembar kegiatan siswa menjadi salah satu alternatif bahan ajar yang akan bermanfaat bagi siswa menguasai kompetensi tertentu, karena lembar kegiatan siswa dapat membantu siswa menambah informasi tentang materi yang dipelajari melalui kegiatan belajar secara sistematis. Erdiana (2017) mengungkapkan bahwa bahan ajar memiliki peranan penting dalam pembelajaran dan membuat mereka belajar tanpa melihat silabus

\section{METODE}

Penelitian ini dilaksanakan di SMA Negeri 5 Padangsidimpuan Kelas $\mathrm{X}$ Tahun Ajaran 2018/2019. Berdasarkan rumusan masalah yang telah dikemukakan maka jenis penelitian yang dilakukan adalah penelitian pengembangan (Research and Development), yang menghasilkan produk. Model yang digunakan dalam pengembangan ini adalah model pengembangan 4-D Model (Four $D$ Model), yang terdiri dari empat tahapan yaitu: pendefenisian (define), perancangan (design), pengembangan (develop), dan penyebaran (dessiminate). Menurut Trianto (2009) penelitian pengembangan adalah metode penelitian untuk mengembangkan produk dan penyempurnaan produk.
Langkah - langkah rancangan pengembangan bahan ajar dapat dirinci 1) Tahap pertama dalam penelitian ini dimulai dengan tahap define. Pada tahap define ini dilakukan penetapan syaratsyarat pembelajaran dengan menganalisis standar kompetensi dan batasan materi pelajaran yang akan diajarkan 2) Tahap ini dilakukan perancangan terhadap bahan ajar yang berbasis model pembelajaran inkuiri berbantuan teka-teki silang. Pada tahap perancangan dilakukan dua tahap, yaitu: penyusunan instrumen yang diperlukan dalam penelitian ini dan perancangan prototype bahan ajar 3) Setelah tahap perencanaan maka masuk ke tahapan selanjutnya yaitu tahapan pengembangan untuk menghasilkan produk pengembangan 4) Langkah ketiga biasa disebut dengan tahapan penyebaran (dessiminate) dengan mempublikasikan bahan ajar yang telah dikembangkan dalam bentuk jurnal

\section{HASIL DAN PEMBAHASAN}

Hasil yang dicapai memperoleh bahan ajar yang valid, praktis dan efektif, setelah dilakukan penelitian diperoleh bahan ajar yang digunakan dalam pelajaran biologi. Adapun pengembangan bahan ajar disesuaikan dengan pendekatan dan model pembelajaran. Maka untuk mencapai tujuan tersebut peneliti melakukan sebuah penelitian pengembangan modul dengan menggwnakan model pengembangan 4D yang dikembangkan oleh Thiagarajan, dan Semmel (Trianto, 2009). Yang meliputi empat tahapan dalam mengembangkan sebuah produk yaitu Pendefinisian, perancangan, pengembangan dan penyebaran

Dalam proses uji coba untuk memperoleh bahan ajar yang valid, praktis dan efektif; dilakukan observasi awal, uji coba (uji coba I dan uji coba II dilaksanaan pembelajaran di kelas) dengan menggunakan bahan ajar yang telah disusun dan dikembangkan sebagai alat ukur keterlaksanaan dan keefektifan perangkat 
Fitri Agustina dan Jalilah Azizah. Pengembangan Bahan Ajar dengan Menggunakan...

pembelajaran.

\section{A. Tahap I. Pendefinisian (Deftne)}

Analisis Awal-Akhir dirancang bahan ajar berupa modul sebagai sumber belajar dengan harapan siswa dapat berkratifitas secara aktif dan bisa belajar sendiri Analisis Siswa Padangsidimpuan didapatkan data bahwa siswa di kelas $\mathrm{X}$ adalah siswa yang cukup heterogen. Hal ini " dari tingkat kognitif berada di kisaran baik dengan ratarata antara 70-80, dan dalam proses pembelajaran juga jarang dilatih mengkonstruk pengetahuan/ konsep selama proses penyelidikan.

Setelah dilakukan Analisa awal-akhir maka dilakukan analisa konsep yang akan diajarkan berkaitan dengan analisis materi yang akan dipelajari siswa, yaitu dengan membuat peta konsep yang akan memudahkan siswa dalam memahami materi pelajaran.

Pada analisis tugas, dilakukan identifikasi keterampilan utama yang diperlukan dalam materi ekosistem dan yang sesuai dengan kurikulum 2013.

Perumusan Tujuan Pembelajaran Perumusan tujuan pelajaran berguna untuk merangkum hasil dari analisis konsep dan analisis tugas untuk menentukan perilaku objek penelitian.

\section{B. Tahap II. Penancangan (Design)}

Tujuan dari tahap ini adalah merancang perangkat Pembelajaran untuk materi ekosistem berbasis pendekatan saintifik yaitu berupa Modul, RPP dan LKS serta merancang tes.

\section{Tahap III. Pengembangan (Develop)}

Hasil dari tahap define dan design menghasilkan rancangan awal sebuah perangkat pembelajaran yang disebut dengan draf I. Setelah perangkat pembelajaran di desain dalam bentuk draf I, maka dilakukan uji validitas terhadap pakar/ (expert review).

Hasil validasi dapat dilihat bahwa tes kemampuan layak digunakan dengan catatan perbaikan dari tim validator. Sehingga dari perangkat pembelajaran valid.
Tabel 1. Rekapitulasi Hasil Validasi Perangkat Pembelajaran

\begin{tabular}{|c|c|c|c|}
\hline No & $\begin{array}{c}\text { Perangkat yang } \\
\text { dinilai }\end{array}$ & $\begin{array}{c}\text { Rata- } \\
\text { rata }\end{array}$ & $\begin{array}{c}\text { Kriteria Hasil } \\
\text { Validasi }\end{array}$ \\
\hline 1 & Modul & 4,28 & Valid \\
\hline 2 & RPP & 4,25 & Valid \\
\hline 3 & LKS & 4,06 & Valid \\
\hline 4 & Tes Kreatifitas & & Revisi kecil \\
\hline
\end{tabular}

Berdasarkan hasil validasi terhadap Modul, RPP, LKS dan tes kreatifitas diperoleh keterangan bahwa semua validator mengatakan bahwa perangkat yang dikembangkan valid. Dengan melalui proses perbadcan maka Modul, RPP, LKS dan tes kemampuan kreatifitas dapat diujicobakan. Perangkat pembelajaran dan instrumen yang diujicobakan pada siswa kelas X SMA Negeri 5 Padangsidimpuan yang berjumlah 30 orang siswa. Adapun hasil uji coba perangkat pembelajaran dan instrumen penelitian adalah sebagai berikut:

\section{a. Hasil Uji Coba Lapangan I}

Perangkat pembelajaran yang sudah valid, maka selanjutnya diuji cobakan di lokasi penelitian yaitu siswa kelas X-3 SMA Negeri 5 Padangsidimpuan dengan jumlah siswa 30 orang siswa. Uji coba dilakukan sebanyak 4 kali pertemuan sesuai dengan RPP.

Uji coba lapangan I dilakukan untuk mengukur keefektifan perangkat pembelajaran yang dikembangkan dengan menggunakan pembelajaran berbasis pendekatan Saintifik yang bertujuan untuk meningkatkan kreatifitas siswa. Berikut adalah penjabaran hasil pada uji coba lapangan I.

\section{Hasil Keefektifan Draf II pada Uji Coba Lapangan I.}

Maka sebuah modul dikatakan efektif jika modul pembelajaran secara positif berdampak pada usaha pengembangan kurikulum siswa. Modul dikatakan efektif ditinjau dari:

a) Tingkat penguasaan siswa terhadap kemampuan penyelesaian tugas. Tes diberikan setelah 3 pertemuan Pembelajaran, tujuannya adalah untuk mengetahui bagaimana tingkat 
PeTeKa (Jurnal Penelitian Tindakan Kelas dan Pengembangan Pembelajaran)

Vol 2 No 1 Tahun 2019 Hal 14 - 21

penguasaan dan ketuntasan siswa terhadap mata pelajaran yang telah dipelajarinya (tabel 3).

b) Pencapaian persentase "baik" untuk kreatifitas siswa. Untuk menentukan persentase kreativitas siswa peneliti dibantu oleh dua orang pengamat yang mengamati sesuai dengan indikatorpersentase pencapaian (tabel 4).

\section{Hasil Revisi Uji Coba Lapangan I Draf II}

Terdapat beberapa hal yang penting untuk diperbaiki selama masa uji coba. Pertama, dalam kegiatan merepresentasikan masalah, siswa masih kebingungan dalam mengisi tahapan mempresentasikan secara visual yang dikaitkan dengan modul Apa apa saja yang harus ditulis, siswa masih. belum paham. Sementara masalah-masalah itu sudah jelas dicantumkan pada modul.

Kedua, siswa masih tidak mengikuti petunjuk peyelesaian yang terdapat dalam LKS, padahal petunjuk sudah diberikan sehingga belum bisa mengerjakan soal dengan cepat. Siswa langsung dengan cepat bertanya kepada guru mengenai apa yang akan digunakan. Pada modul ada beberapa hal yang harus direvisi seperti pada materi. Hasil perbaikan atau revisi yang dilakukan dari hasil uji coba lapangan I ini dinamakan dengan draf III. Yang akan diuji cobakan kembali pada uji coba II yang bertujuan untuk menghasilkan kualitas modul biologi yang memenuhi kevalidan, kepraktisan dan keefektifan yang baik

Tabel 3. Deskripsi Hasil Tes Kreatifitas Siswa pada Uji Coba I

\begin{tabular}{|c|c|c|c|c|}
\hline No & $\begin{array}{c}\text { Interval } \\
\text { Nilai }\end{array}$ & $\begin{array}{c}\text { Jumlah } \\
\text { Siswa } \\
\text { (orang) }\end{array}$ & $\begin{array}{c}\text { Persentase } \\
\text { (\%) }\end{array}$ & $\begin{array}{l}\text { Kategori } \\
\text { Penilaian }\end{array}$ \\
\hline 1. & $90-100$ & 5 & $16 \%$ & Sangat tinggi \\
\hline 2. & $80-89$ & 6 & $20 \%$ & Tinggi \\
\hline 3. & $65-79$ & 11 & $36 \%$ & Cukup \\
\hline 4. & $55-64$ & 6 & $20 \%$ & Rendah \\
\hline 5. & $0-54$ & 2 & $6,6 \%$ & Sangat rendah \\
\hline & Total & 30 & $100 \%$ & \\
\hline
\end{tabular}

Tabel 4. Hasil Analisis Observasi Kreatifitas Siswa Pada Uji Coba I

\begin{tabular}{|c|c|c|c|c|}
\hline \multirow{2}{*}{$\begin{array}{l}\text { Kategori } \\
\text { Kreatifitas } \\
\text { Siswa }\end{array}$} & \multicolumn{4}{|c|}{$\begin{array}{c}\text { Kadar Kreatifitas Siswa per } \\
\text { Pertemuan }\end{array}$} \\
\hline & I & II & III & IV \\
\hline $\begin{array}{l}\text { 1. Memiliki rasa } \\
\text { ingin tahu }\end{array}$ & $33 \%$ & $46 \%$ & $53 \%$ & $53 \%$ \\
\hline \begin{tabular}{|l|} 
2. \\
Mengajukan \\
kreatif
\end{tabular} & $20 \%$ & $20 \%$ & $56 \%$ & $56 \%$ \\
\hline $\begin{array}{l}\text { 3. } \text { Memberikan } \\
\text { banyak } \\
\text { gagasan dan } \\
\text { usul }\end{array}$ & $17 \%$ & $46 \%$ & $63 \%$ & $63 \%$ \\
\hline \begin{tabular}{|ll} 
4. & Kreatif \\
menyatakan \\
pendapat
\end{tabular} & $33 \%$ & $20 \%$ & $56 \%$ & $33 \%$ \\
\hline 5. $\begin{array}{l}\text { Mempunyai } \\
\text { daya imajinasi }\end{array}$ & $10 \%$ & $30 \%$ & $40 \%$ & $63 \%$ \\
\hline
\end{tabular}

\section{b. Hasil Uji Coba Lapangan II}

\section{Hasil Kepraktisan Draf II pada Uji Coba Lapangan I}

Pada uji coba iapangan II ini salah satu tujuannya adalah untuk melihat kepraktisan draf III. Aspek kepraktisan dari material yang dikembangkan ini adalah dilihat dari apakah siswa atau pengguna dapat menggunakan material tersebut dengan mudah. Bagi siswa dapat digunakah secara madiri diluar jam pelajaran.

Komponen pembelajaraa yang terdiri dari modul, rpp, lks dan tes kemampuan kreatifitas (draf II) dikatakan praktis jika hasil dari penelitian menunjukkan bahwa para siswa sebagai pengguna menganggap bahwa komponen pembelajaran tersebut memenutn kebutuhan, harapan, dan batasan batasan. Salah satunya penilaian ahli bahwa komponen pembelajaran tersebut yang dibuat dapat digunakan dengan sedikit atau tanpa revisi.

\section{Hasil Keefektifan Draf III pada Uji Lapangan II}

Sebelumnya sudah dijelaskan bahwa sebuah material yang dikembangkan memiliki kualitas yang baik apabilaa 
Fitri Agustina dan Jalilah Azizah. Pengembangan Bahan Ajar dengan Menggunakan...

memenuhi tiga hal yaitu kevalidan, kepraktisan dan keefektifan. Jadi perangkat pembelajaran yang terdiri dari modul, rpp, lks dan tes yang digunakan harus dapat menimbulkan pengaruh yang signifikan. Modul dikatakan efektif ditinjau dari: (a)Tingkat penguasaan siswa; (b) Pencapaian persentase baik pada kreatifitas siswa.

\section{1) Tingkat Penguasaan Kreatifitas Siswa}

Dalam penelitian tingkat penguasaan siswa ditinjau dari kreatifitas siswa dengan menggunakan tes. Tes diberikan setelah 4 pertemuan pembelajaran tujuannya adalah untuk mengetahui bagaimana tinkat penguasaan dan ketuntasan siswa terhadap materi pelajaran yang telah dipelajarinya. Adapun hasil tes dapat dilihat Pada. lampiran, secara umum hasil tes siswa pada kemampuan representasi biologi dapat dilihat pada tabel 5 .

Dari tabel 5 diperoleh bahwa ratarata nilai kemampuan tes siswa sebesar 80 dimana terdapat 6 orang siswa atau 20\% yang tingkat kemampuan tes berada pada kategori "sangat tinggi' ; 17 orang atau 56\% pada kategori "tinggi", 2 orang siswa atau 6,6\% pada kategori "cukup" dan 5 orang siswa atau 16\% kategori "rendah”.

Tabel 5. Deskripsi Hasil Tes Siswa pada Uji coba II

\begin{tabular}{|c|c|c|c|c|}
\hline No & $\begin{array}{c}\text { Interval } \\
\text { Nilai }\end{array}$ & $\begin{array}{c}\text { Jumlah } \\
\text { siswa } \\
\text { (orang) }\end{array}$ & $\begin{array}{c}\text { Persentasi } \\
\mathbf{( \% )}\end{array}$ & $\begin{array}{c}\text { Kategori } \\
\text { Penilaian }\end{array}$ \\
\hline 1 & $90-100$ & 6 & 20 & Sangat tinggi \\
\hline 2 & $80-89$ & 17 & 56 & Tinggi \\
\hline 3 & $65-79$ & 2 & 6,6 & Cukup \\
\hline 4 & $55-64$ & 5 & 16 & Rendah \\
\hline 5 & $0-54$ & 0 & 0 & Sangat rendah \\
\hline \multicolumn{2}{|c|}{ Total } & 30 & 30 & 100,0 \\
\hline \multicolumn{5}{r}{}
\end{tabular}

Secara klasikal tingkat kemampuan tes siswa sebesar 83\%. Hal ini menunjukkan bahwa tingkat kemampuan siswa telah memenuhi syarat. Sehingga dapat disimpulkan bahwa hasil tes siswa pada uji coba lapanga II sudah memenuhi kriteria ketuntasan secara klasikal.

\section{2) Hasil Pencapaian Persentase Kreatifitas Siswa}

Hasil perolehan persentase pencapaian kruntuk empat kreatifitas pertemuan secara lengkap dapat dilihat pada lampiran. Pada table 6 akan dijabarkan secara singkat persentase pencapaian "baik” kreatifitas siswa.

\begin{tabular}{|l|c|c|c|c|}
\hline \multirow{2}{*}{$\begin{array}{c}\text { Kategori } \\
\text { Kreatifitas } \\
\text { Siswa }\end{array}$} & \multicolumn{4}{|c|}{$\begin{array}{c}\text { Kadar Kreatifitas Siswa per } \\
\text { Pertemuan }\end{array}$} \\
\cline { 2 - 5 } & I & II & III & IV \\
\hline $\begin{array}{l}\text { Memiliki rasa } \\
\text { ingin tahu }\end{array}$ & $36 \%$ & $53 \%$ & $73 \%$ & $76 \%$ \\
\hline $\begin{array}{l}\text { Mengajukan } \\
\text { pertanyaan } \\
\text { kreatif }\end{array}$ & $33 \%$ & $60 \%$ & $60 \%$ & $66 \%$ \\
\hline $\begin{array}{l}\text { Memberikan } \\
\text { banyak } \\
\text { gagasan dan } \\
\text { usul }\end{array}$ & $33 \%$ & $46 \%$ & $63 \%$ & $80 \%$ \\
\hline $\begin{array}{l}\text { Kreatif } \\
\text { menyatakan } \\
\text { pendapat }\end{array}$ & $73 \%$ & $83 \%$ & $83 \%$ & $86 \%$ \\
\hline $\begin{array}{l}\text { Mempunyai } \\
\text { daya imajinasi }\end{array}$ & $40 \%$ & $66 \%$ & $80 \%$ & $76 \%$ \\
\hline
\end{tabular}

Kreatifitas siswa untuk setiap kategori dapat kita lihat peningkatannya dan pencapaian kriteria "baik" dapat dicapai setelah selesai perlakuan "Prilaku siswa yang tidak relevan dengan KBM hampir tidak ditemukan karena pembelajaran dengan menggunakan modul sudah mulai dimengerti dan dipahami siswa.

Berdasarkan uraian di atas, terlihat kadar kreatifitas siswa, untuk 5 (lima) kategori berada pada batas kriteria :baik" mencapai $77 \%$ telah mencapai ketuntasan capaian yaitu $75 \%$. Setelah merujuk kriteria keefektivan kreatifitas seperti yang direncanakan dalam penelitian ini maka disimpulkan bahwa penelitian ini berhenti pada waktu kategori yang telah ditetapkan.

\section{Tahap IV. Penyebaran (Diminisiate)}

Pengembangan bahan ajar secara keseluruhan mencapai tahap akhir dimana 
PeTeKa (Jurnal Penelitian Tindakan Kelas dan Pengembangan Pembelajaran)

Vol 2 No 1 Tahun 2019 Hal 14 - 21

modul ini telah memperoleh penilaian positif dari tenaga ahli dan melalui tes pengembangan. Modul dalam penelitian ini dilakukan penyebaran secara terbatas hanya pada sekolah mitra saja yaitu SMA Negeri 5 Padangsidimpuan dari materi, kelas/siswa dan waktu (Penyebaran khusus) Setelah bahan ajar final, modul biologi yang telah dikembangkan disebarkan untuk dapat digunakan path semester berikutnya dalam materi ekosistem.

Dalam mengembangkan bahan ajar dengan meng,gunakan model pengembangan Thiagarajan, Semmel dan Semmel ditempuh melalui 4 tahapan yang selanjutnya lebih dikenal dengan singkatan 4D yaitu define, desigm develop, dan disseminate. Akhir dari pengembangan ini adalah menghasilkan produk berupa rpp, modul, lembar kerja siswa dan beserta instrumennya, sejalan dengan Sugiyono (2011) mengemukakan bahwa penelitian pengembangan yang digunakan untuk menghasilkan produk tertentu dan menguji keefektifan produk tersebut Namun dalam mengembangkan perangkat pembelajaran ini harus diuji kualitasnya, seperti kevalidannya, kepraktisan serta keefektifannya.

Seperti yang telah dikemukan Nieveen (2007)) suatu material dikatakan berkualitas jika memenuhi aspek aspek, antara lain: validitas (validity), kepraktisan (practicality), dan keefektifan (effectiveness). Sehingga bahan ajar pembelajaran yang dikembangkan ini akan layak digunakan oleh siswa dan guru di dalam pembelajaran jika ketiga ha1 ini sudah terpenuhi sesuai dengan indikatorindikatornya. Untuk mengetahui validitas, kepraktisan dan keefektifan dapat dijelaskan sebagai berikut.

\section{1) Validitas Bahan Ajar Biologi untuk Meningkatkan Kreatifitas Siswa}

Menurut Sugiyono (2011) untuk memperoleh data maka harus digunakan instumrn yang valid. Valid berarti instrumen tersebut dapat digunakan untuk mengukur apa yang seharusnya diukur.

Tabel 7. Hasil Validasi Perangkat Pembelajaran oleh Tim Ahli

\begin{tabular}{|c|c|c|c|}
\hline No & $\begin{array}{c}\text { Perangkat } \\
\text { yang di } \\
\text { nilai }\end{array}$ & Rata-rata & $\begin{array}{c}\text { Kriteria Hasil } \\
\text { Validasi }\end{array}$ \\
\hline 1 & Modul & 4,27 & Valid \\
\hline 2 & RPP & 4,34 & Valid \\
\hline 3 & LKS & 4,51 & Sangat Valid \\
\hline 4 & Tes & & $\begin{array}{c}\text { Revisi kecil } \\
\text { dan tanpa } \\
\text { revisi }\end{array}$ \\
\hline
\end{tabular}

Berdasarkan tabel 6 dapat dilihat bahwa hasil validasi untuk masing-masing komponen pembelajaran yang dikembangkan berada pada kategori "Valid" dan "Sangat valid" dengan nilai rata rata masing masing komponen yaitu 4,27, 4,34, dan 4,51 serta untuk tes kemampuan representasi biologi berada pada kategori revisi kecil dan tanpa revisi. Hal ini menunjukkan bahwa komponen pembelajaran yang dikembangkan sudah dapat digunakan untuk mengukur apa yang hendak di ukur.

\section{2) Efektivitas Modul Biologi Untuk Meningkatan Kreatifitas Siswa}

Peningkatan kreatifitas siswa dilihat berdasarkan hasil test kemampuan siswa pada ujicoba I terdapat 19 orang siswa atau $63 \%$ dari 30 siswa yang mengikuti test yang tingkat kemampuan tes berada pada kategori minimal "Cukup". Sementara pada ujicoba II terdapat 25 orang siswa atau 83\% kategori 'baik”. Jadi melalui modul berbasis masalah dapat meningkatkan kemampuan siswa dalam menerapkan kreatifitas biologi. Dengan demikian pembelajaran biologi melalui modul menggunakan pendekatan Saintifik dapat meningkatkan kreatifitas biologi siswa.

\section{SIMPULAN}

Dari penelitian yang telah dilakukan maka dapat disimpulkan bahwa kemampuan siswa mengalami peningkatan dengan 
Fitri Agustina dan Jalilah Azizah. Pengembangan Bahan Ajar dengan Menggunakan...

melihat pada kenaikan ketuntasan klasikal siswa dari sebesar $36 \%$ pada siklus I menjadi $83 \%$ pada siklus II. Kenaikan ini akibat penggunaan media pembelajaran yang sudah dikembangkan melalui beberapa tahapan yaitu define, design, develop dan desiminate.

\section{DAFTAR PUSTAKA}

Darmawangsa, Rio. (2017). Pengembangan Instrumen Sikap Siswa Sekolah Menengah Atas Terhadap Mata Pelajaran Fisika. Universitas Jambi : Jambi.

Depdiknas. (2008). Panduan Pengembangan Bahan Ajar. Jakarta : Direktorat Pembinaan Sekolah Menengah Atas

Erdiana. (2017) Pengembangan bahan ajar inovatif melalui pendekatan saintifik pada pengajaran termokimia. Jurnal kimia saintek dan pendidikan volume 1,nomor 1, tahun 2017, hal 22-29 e-ISSN 2615-3378.

Lufri, (2007). Strategi Pembelajaran Biologi Teori, Praktek dan Penelitian. Padang: UNP Press

Nieveen, N. 2007. An Introdution To Education Design Research. Dapat dilihat di www.slo.nl/organisatie/ international/

Sugiyono. (2011). Metode Kuantitatif, Kualitatif dan $R \& D$. Bandung: CV. Alfabeta

Trianto. (2009). Mendesain Model Pembelajaran - Progeresif. Jakarta:Kencana Prenada Media Group 